\title{
MODERN TRENDS IN MILITARY AND ECONOMIC POLICY IN THE CONTEXT OF REGIONAL SECURITY
}

\author{
AIGUL TULEMBAYEVA, GANI LESSOV, AMANZHOL RAZBEKOV \& ALEXEY SEMCHENKO
}

National University of Defense of the First President of the Republic of Kazakhstan - Elbasy, Nur-Sultan, Kazakhstan

\begin{abstract}
The analysis of the situation and trends of military-political and military-economic cooperation between the countries of the region, the main issues of military-economic policy in the context of ensuring national and regional security are considered. The main aspects of the new paradigm of economic policy of the state are directly related to the intensification of the movement towards the synthesis of the military economy, the expansion of military-technical cooperation (including in the field of new developments), the use of innovative methods and tools to ensure the military economic policy of both the state and the entire region.

KEYWORDS: Military Policy, Military-Political Situation, Military-Economic Policy, Regional, Collective and National Security, Regional Security, Economic Security, Central Asian Region
\end{abstract}

Received: May 20, 2020; Accepted: Jun 10, 2020; Published: Jun 30, 2020; Paper Id.: IJMPERDJUN2020267

\section{INTRODUCTION}

The current military and political situation in the world is determined by the high dynamism and contradictory nature of the processes and international relations taking place in the world.

The search for new forms of political, economic and military cooperation to address issues of ensuring the security of States and the region is conditioned by the presence of many unresolved problems of a political, socioeconomic, national and religious nature.

Regional security is the most important category that determines the development processes in all spheres of life of countries. This is due to the peculiarity of the current stage of development, both of the States themselves and of the entire Central Asian region, which is currently in an active phase of its formation as a geopolitical unit. In the process, the region's interstate relations with the near and far abroad are undergoing changes. In addition, regionalization is also actualized by the processes of globalization of the economy, politics and security, since these phenomena are simultaneously developing processes.

It should be emphasized that the situation in the region is formed under the influence of numerous factors, largely due to the economic interests of major powers (territory, energy resources and minerals) aimed at strengthening the leading position (positions) in a particular region.

In modern conditions, various forms of influence such as "indirect actions", "hybrid methods of struggle", "information war", as well as political and economic sanctions can be applied to undesirable States (Karapetyan, 2012). 
The situation in the Central Asian region stable, but has a tendency to complication caused by the penetration of religious extremism from the Middle East, and Afghanistan of a possible unification of extremist cells operating in various countries of the region, under the auspices of the so-called terrorist organizations such as "DAISH" and destabilizing the internal political, socio-economic situation of the countries of the region under the influence of "interested" countries with double standards for a democratic approach of the political leadership.

The main problems in the development of the region and relations between countries can be attributed (Korabelnikov, 1999):

- Geopolitical confrontation between major powers whose interests, depending on the situation, may not coincide with the national interests of the countries of the region;

- Growth of religious radicalism, political and religious extremism;

- Increasing the volume of foreign investment and developing the influence of transnational corporations (TNCs);

- $\quad$ Deepening problems with energy and water supply.

These extremely serious problems can set in motion uncontrolled forces and processes, as well as create prerequisites for the destabilization of the situation in the region, the possible aggravation of existing and the emergence of new inter-state and internal conflicts.

In this context, the main tasks of the States of the region will be aimed at maintaining peace and stability, strengthening the system of collective security, within which they will implement political, military and economic integration.

For joint solution of problems of security and strategic stability of the region was formed a military-political Union created by the Commonwealth of Independent States (CIS) on the basis of the Collective Security Treaty (CSTO) and the composition of the secreted coalition forces (CRRF) in the regions of collective security. In order to achieve stability in the region, regional organizations such as the Eurasian economic community, the Conference on interaction and confidence-building measures in Asia (CICA), and the Shanghai cooperation organization (SCO) have been established (Fde-Córdoba,2016).

Based on the interstate agreement the CSTO countries have defined three regions of collective security: Eastern European, Caucasian and Central Asian (hereinafter - CAR) (Creus, 2006).

The purpose of the military policy of the States of the region in solving the problems of ensuring the security of the region will be to create conditions for the use of their national armed forces and coalition forces, taking into account the economic capabilities of countries to resolve possible armed conflicts.

There are many reasons for this development of the situation in the regional security system and its militarypolitical structures, and most of them lie in the peculiarities of the geopolitical, economic, domestic political and military development of the countries of the region and the impact of these processes on a global scale.

Hence, we can conclude that the need to address military-economic policy as an important aspect of this process and the definition of modern trends of the state military-economic policy of States in the integration of regional security. 


\section{RESULTS AND DISCUSSIONS}

The economic aspect considers the nature of economic relations (a common or closely integrated economic space), the presence of common or overlapping economic interests in ensuring the security of the region, which are determined by the military and economic policy of the countries.

Military-economic policy is understood as a system of officially proclaimed views and the state's activity to provide economic support for the country's security problems (Deen, 2009). Military-economic policy is derived from economic and military (defense) policy, which determine the required level of military power and the amount of funds allocated to maintain it.

Below (Table 1) are the main indicators that characterize the economic and military-economic potentials of a number of leading countries in the world in 2018.

Table 1: Economic and Military-Economic Potentials of the World's Leading Countries

\begin{tabular}{|c|l|c|c|c|}
\hline No. & \multicolumn{1}{|c|}{ Country } & Expenses (Billions of Dollars) & Share in the World (\%) & Share in GDP (\%) \\
\hline 1 & USA & 649 & 36 & 3,2 \\
\hline 2 & China & 250 & 14 & 1,9 \\
\hline 3 & Saudi Arabia & 67,6 & 3,7 & 8,8 \\
\hline 4 & India & 66,5 & 3,7 & 2,4 \\
\hline 5 & France & 63,8 & 3,5 & 2,3 \\
\hline 6 & Russia & 61,4 & 3,4 & 3,9 \\
\hline 7 & Great Britain & 50 & 2,7 & 1,8 \\
\hline 8 & Germany & 49,5 & 2,7 & 1,2 \\
\hline 9 & Japan & 46,6 & 2,6 & 0,9 \\
\hline 10 & Republic Of Korea & 43,1 & 2,4 & 2,6 \\
\hline
\end{tabular}

As you know, state authorities and management bodies, military and civilian specialists should take part in the formation of the state's military and economic policy as a means of ensuring military and economic security. The economic sector of the state coordinates the economy with the political objectives of the state, and military requirements, military strategy, derived from facing the state of tasks for ensuring military security.

The goals of the military and economic policy of the state are achieved by solving a number of main tasks, such as:

- Ensuring military and economic security, maximum achievement of compliance with military goals and economic capabilities of States;

- Improving the efficiency of economic security;

- Maintaining the necessary military power with as little diversion of limited resources as possible.

- Historical experience shows that mistakes in assessing the economic possibilities of military preparations usually have disastrous consequences.

- When considering the economic aspects of the functioning of regional security systems, the following points should be kept in mind:

- The position of the region as a determinant of its place, role and prospects in the world community; 
- The importance of economic integration and regionalization as an integral part of the strategy of space tightening and control;

- Taking into account the existence of economic projects and economic interests not only of regional security participants, but also of other countries.

The Central Asian region under the influence of globalization and the development of technological progress is a raw material appendage remote from world markets. The main potential of the region can be the presence of transit and energy highways, the development of which can become the basis for ensuring the security of the region.

The main geopolitical factor determining the need for economic integration of the region is geographical proximity, contiguity of the territory, cultural and civilizational community of peoples, the existence of common external threats, the nature of relations between countries, and others. Despite this, the processes of economic integration in the region are proceeding at a slow pace, this is due to a number of reasons, the main of which are different rates and models of economic reform, different rates of economic growth and the impact of various negative processes in the world economy.

Economic factors significantly influence the creation and development of a regional security system. The military and economic policy of the state is carried out in order to formulate the main provisions of the concept and determine the main areas of activity for the economic support of defense. These provisions follow from the analysis of the current state of military and economic security.

Military and economic security integrates two different areas of national security - military and economic security of the state and is directly related to ensuring the country's defense capability.

Thus, the military and economic security of a state is a state of protection of the country's economic complex from external and internal military threats, in which it is able to meet the needs of the state's military organization, sustainably maintain the necessary military power and realize the country's military and economic potential.

The most general, basic concept is the category of "military-economic potential". Indicators of economic potential give an idea of the economic opportunities of various countries, the degree of economic security of national security.

The military-economic potential is a part of the economic potential (economic power) that can be used and is used in the interests of the state (a coalition of States) in order to solve military-political tasks. The military-economic potential is the maximum possible volume of military production that can be achieved for comprehensive support, first of all, of the armed forces, training and conduct of war.

Military-economic security implies a state of the military sector of the economy that provides for the satisfaction of the defense needs of States in peacetime and wartime. In table. 2 shows the military expenditures of the CAR countries. 
Table 2: Military Expenditure of the Countries of the Central Asian Region

\begin{tabular}{|c|c|c|c|c|c|c|}
\hline \multirow[t]{2}{*}{ Countries } & \multicolumn{5}{|c|}{$\begin{array}{c}\text { Military Expenditures in Millions of US Dollars } \\
\text { (in Current Prices by Year) }\end{array}$} & \multirow[t]{2}{*}{ Note } \\
\hline & 2014 & 2015 & 2016 & 2017 & 2018 & \\
\hline Kazakhstan & 2306,5 & 2046,2 & 128,1 & 1390,6 & 1613,6 & \\
\hline Kyrgyzstan & 128,0 & 117,0 & 115,6 & 121,5 & 121,2 & \\
\hline Turkmenistan & 104,3 & 95,8 & - & - & - & \multirow{3}{*}{ Data is not provided } \\
\hline Tajikistan & - & - & - & - & - & \\
\hline Uzbekistan & - & - & - & - & - & \\
\hline
\end{tabular}

As a specific direction, the state military and economic policy covers the system of relations between economic entities to meet the military needs of society and aims to find optimal ways to solve a complex of military and economic problems to ensure the economic security of the state.

The analysis (Gasem, 2013)shows that in modern conditions the most important problems of economic security of the States of the region are: the impact of the global financial crises, natural resource depletion, high degree of commodity dependence of the country from imported energy, the foreign trade deficit, relatively high inflation, the use of imperfect technologies, have a large number of unprofitable or hidden-unprofitable enterprises, reduced investment in the real sector of the economy, restriction of the rights of producers, etc.

Taking into account the above-mentioned problems of ensuring military and economic security, it is necessary to consider its most important components:

- Military and economic self-sufficiency, that is, the ability of the state to meet basic military needs at the expense of its own resources, both in peacetime and in wartime;

- Reliability and stability of the military sector of the economy;

- The ability of the military economy to develop its scientific and technical capabilities in such a way that the satisfaction of current and future military and economic needs is carried out at a minimum cost of all types of resources;

- Availability of mobilization capabilities for the deployment of military production.

At the same time, the main structural elements of military and economic security will be determined: technological, technical and production, currency and credit, information, food, raw materials, energy, and environmental components.

\section{CONCLUSIONS}

World and regional development at the present stage is characterized by a weakening of ideological confrontation, a decrease in the level of economic, political and military influence of some States (groups of States) and unions, and an increase in the influence of other States that claim comprehensive dominance.

There are still many unresolved regional problems and international relations. There are still trends of their complication, including in the CAR. The existing institutions of the international security system, including its international legal mechanisms, do not ensure equal security for all States. 
Based on the above, in order to strengthen the military and economic security of the States of the region, the following directions of the state's military economic policy can be determined:

- Improving the efficiency of the economy, putting it on an innovative path of development;

- Strengthening the country's military and economic potential;

- Scientific and technical transformations in production and defense industry;

- Military and economic cooperation with the countries of the region.

At the same time, there is a need to define internal and external mechanisms for ensuring military and economic security.

Internal economic mechanism of providing military-economic security is the creation of a socially oriented market economy, transition to market relations in the sphere of military production and improvement of material and technical equipment of the Armed Forces.

The foreign economic mechanism for ensuring the military and economic security of the state is:

- Development of economic relations with the States of the region and foreign countries;

- Improving the competitiveness of the national economy;

- Expanding trade in weapons and military products.

Strategically important for the region's security, from the point of view of military and economic security, is cooperation with the CIS countries in the engineering, fuel and energy, and transport and communication complexes, which are the most integrated parts of the Commonwealth. The priority tasks here will be:

preservation and further development of the machine-building complex; improvement of unified energy and railway systems, oil and gas production and transportation systems; creation of new transport corridors for accelerated transit of cargo flows; implementation of a coordinated tariff policy in transport and communications.

Analysis of the course of economic transformations in our country, allocated funds from the state budget for defense (Fig. 1), trends in the development of foreign economic relations, the experience of creating the country's defense complex, integration processes within the framework of creating a system of collective security and the impact of these factors on economic security allows us to draw a number of fundamental conclusions:

- The Current state of the economy and the strengthening of its economic security require deep structural changes in its military-industrial complex, acceleration of scientific and technological progress, and widespread introduction of new technologies into production.

- Military and economic security of the Republic of Kazakhstan implies comprehensive improvement of internal and external economic mechanisms for its provision.

- To strengthen the country's military and economic security, it is necessary to create a high-tech military-industrial complex. 
- The most important lever to strengthen military-economic security of the state are economic integration, the creation of a single economic space, improvement of the system of collective security of the CSTO member States in the framework of the SCO and other organizations.

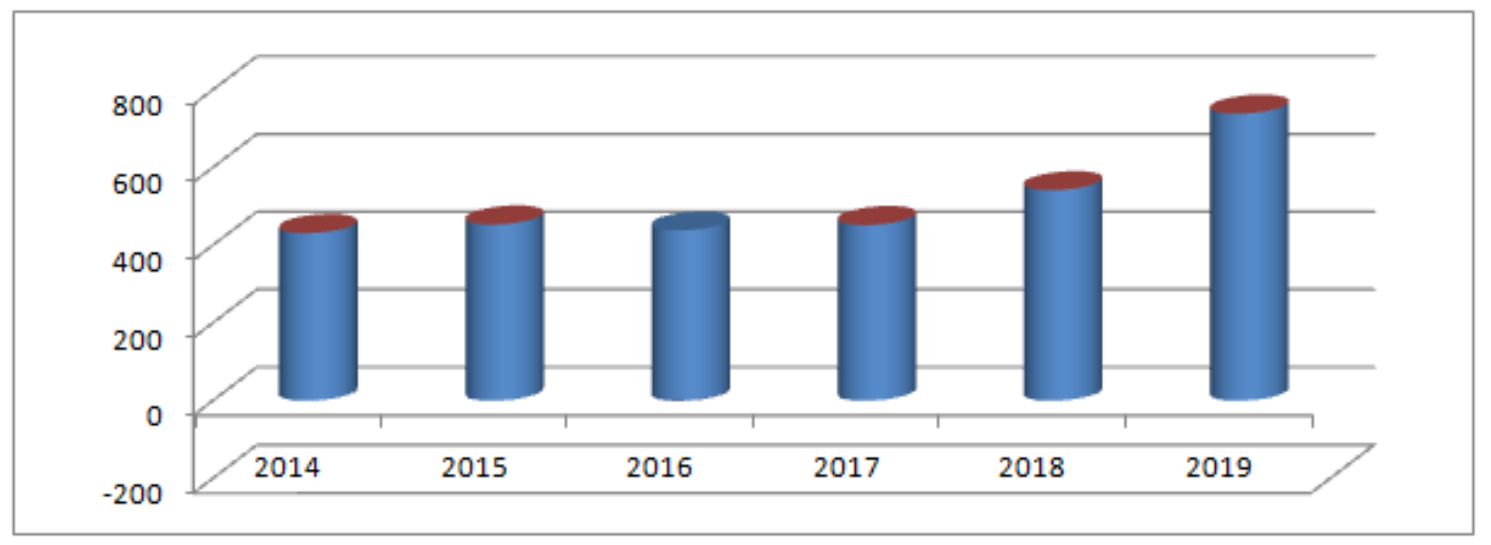

Figure 1: State Budget Expenditures on Defense (Billion Tenge).

Thus, in modern conditions, more than ever, the problems of development of the military-economic sector, including its innovative component and the role of this component in innovative development, as well as the content and prospects of interaction to strengthen the economic security of the region's countries should be based on the following areas:

- Improvement of the state foreign economic policy based on multi-vector approach and the established practice of international division of labor and markets of goods and services;

- Rational use of the geographical location of countries, development of an effective system of servicing international transport arteries and communications;

- Increasing the knowledge intensity of manufactured products, developing the service sector for its maintenance;

- Development of business cooperation with the countries of the region participating in the multilateral system of trade regulation, with the prospect of full participation in the world trade organization;

- Creating and maintaining a healthy and attractive investment climate in the countries of the region;

- Improving economic and legal conditions that hinder economic development;

- Strengthening military and economic power through a multi-vector economic policy;

- Modern and well thought out methods of planning the construction and development of the armed forces and the military organization of States as a whole and within the framework of the collective security system;

- Optimize the scale and structure of the military economy and maximize its convergence with the civil economy;

- Transfer of the military-economic complex to market relations while maintaining the control function of the state;

- Creating a system of international military-economic relations. 
The implementation of all these measures to ensure regional security, taking into account current trends in military and economic policy, will ensure the stability and development of the military economy of an individual state, as well as on the scale of the region as a whole.

The main aspects of the new paradigm of economic policy of the state are directly related to the intensification of the movement towards the synthesis of the military economy, the expansion of military-technical cooperation (including in the field of new developments), the use of innovative methods and tools to ensure the military economic policy of both the state and the entire region.

\section{ACKNOWLEDGEMENTS}

This article is published as part of the research work of program-targeted funding № BR 05236855 "Military-technical and military-technological support of the defense and security of the Republic of Kazakhstan on the basis of economic pragmatism".

\section{REFERENCES}

1. Arun, M., H. Chandrashekar, and Babu B N Pradeepa. "Regional Convergence or Divergence? A District Level Analysis of Agriculture In Karnataka. "International Journal of Agricultural Science and Research (IJASR) 6. 5, Oct 2016, 75-84

2. Baizakova. Regional Security Cooperation Between the Republic of Kazakhstan and the European Union https: //doi.org/10.2753/RUP1061-1940510106

3. Karapetyan A. R. Military-political cooperation of Russia with the CIS countries as a factor of integration. ISPI RAS, Moscow, 2001.Marcel De Haas (2015) Kazakhstan's Security Policy: Steady as She Goes?, The Journal of Slavic Military Studies, 28:4, 621-645, DOI: 10.1080/13518046.2015.1094939.

4. Jebel, Ameni. "Tunisia's Domestic Politics and Foreign Policy from President Bourguiba to PresidentMarzouki." International Journal of Political Science, Law and International Relations (IJPSLIR) 4.

5. Korabelnikov A. A. Topical issues of creation and use of military contingents in the collective rapid response forces of the collective security Treaty organization // Academy of military Sciences of the Russian Federation / Moscow, 2012.Bоенная экономика. Теория и актуальные проблемы / Под ред. А.И. Пожарова. Москва, 1999.

6. Gonzalo F-de-Córdoba \& José L. Torres (2016) National security, military spending and the business cycle, Defence and Peace Economics, 27:4, 549-570,https://doi.org/10.1080/10242694.2014.891353.

7. Creus, J., Brezault, F., Rebere, C., and M. Gadouleau (2006). Synthesis and characteri-sation of thin cerium oxide coatings elaborated by cathodic electrolytic deposition on steel substrate, Surf. Coat. Technol. 200, 14-15.

8. Deen, K. M., Ahmad, R., and I.H. Khan (2009). Corrosion Protection Evaluation of Mild Steel Painted Surface by Electrochemical Impedance Spectroscopy. Journal of Quality and Technology Management, 5, 1, 6.

9. Durodola, B. M., Olugbuyiro, J. A. O., Moshood, S. A., Fayomi, O. S. and A.P.I. Po-poola (2011). Study of Influence of Zinc Plated Mild Steel Deterioration in Seawater Environment. Int. J. Electrochem. Sci., 6, 5605 - 5616.

10. Davydov V. M., Zuev V. V., Ponochevny P. N. (2013). Analysis of international practice of profile and three-dimensional surface roughness assessment. Electronic scientific publication Scientific notes of the Pacific state University, 4 (4), 1061 1074.

11. Fayomi O. S. I. and A.P.I Popoola (2012). An Investigation of the Properties of Zn Coated Mild Steel, Int. J. Electrochem. Sci., $7,6555-6570$. 
12. Gasem, Z.M. (2013). ME 472: Corrosion engineering 1, ocw.kfupm.edu.sa/ocw.courses/users062/ME4720102/LectureNotes/impact of Corrosion.pdf, accessed on 26/01/2013.

13. Guosheng, H. Gu Daming, g., Li Xiangbo, L., and X. Lukuo (2013). Corrosion Behavior of Oxyacetylene Flame Sprayed Zn-Ni Composites Coating with Spray-dried Agglomerating Powders in Natural Seawater, Int. J. Electrochem. Sci., 82905 - 2917.

14. Hammer, P., F. C. dos Santos, B. M. Cerrutti, S. H. Pulcinelli and C. V. Santilli (2012). Corrosion Resistant Coatings Based on Organic-Inorganic Hybrids Reinforced 264 Developments in Corrosion Protection by Carbon Nanotubes, Recent Researches in Corrosion Evaluation and Protection, Prof. Reza Shoja Razavi (Ed.), ISBN: 978-953-307-920-2.

15. Hara, M., Ichino, R., Okido, M., and N. Wadab (2003). AlN formation and enhance-ment of high-temperature oxidation resistance by plasma-based ion implantation, Surf. Coat. Technol. 169-170, 359-362.

16. Hunag, Y. and J. Chen (2012). The Development of an Anti-corrosion Wrapping Tape and its Corrosion Protection Effect Evaluation on Mild Steel in Marine Splash Zone, Int. J. Electrochem. Sci., 7, 7121 - 7127.

17. Ige, O.O., Shittu, M.D., Oluwasegun, K.M., Olorunniwo, O.E. and Umoru, L.E. (2012). Eco-friendly Inhibitors for Erosioncorrosion Mitigation of API-X65 Steel in CO2 En-vironment, Ife Journal of Technology, 21 (2), 43 - 48.

18. Makangali, Bauyrjan; Amirbekova, Sagynysh; Khamitova, Marvan; Baydarov, Erkin (2020). Religious aspects of the syrian crisis on social media. Central Asia \& the Caucasus (14046091). 7/12/1905, Vol. 21 Issue 1, p102-111. 10p

19. Sydyknazarov, Mukhit-Ardager \& Karzhaubay, Janel \& Sydyknazarova, Saltanat \& Bayurzhan, Makangali. (2018). Values of the Youth of Kazakhstan. New Educational Review. 52. 137-148. 10.15804/tner.2018.52.2.11.

20. Somzhurek B.Zh, A.M. Yessengaliyeva, Zh.M. Medeubayeva, B.K. Makangali; Central Asia and regional security. Communist and Post-Communist Studies 1 June 2018; 51 (2): 161-171. doi: https://doi.org/10.1016/j.postcomstud.2018.04.005

21. Polyansky S. N., Butakov S. V., Alexandrov V. A., Lazareva L. Yu. Surface preparation for applying anticorrosive coatings on metal structures and details of mechanisms made of carbon steels. Modern problems of science and education, $2014,4$.

22. Punekar, Sarika, and R. Gopal. "A Study to IdentifyCustomer's Online Apparel Shopping Behavior in Relation to Return Policies of E-Commerce Businesses, WR To Pune Region, India." International Journal of Sales \& Marketing, Management Research and Development (IJSMMRD) 6.3 (2016): 1-6.

23. Suslov A. G., Bezylazny V. F., Panfilov Yu. V. (2008). Engineering of surfaces of details. - Moscow: Mashinostroenie, 316.

24. Zhaoxin Rena, Bing Wangb, Gaoming Xiangb, Dan Zhaoc, Longxi Zhenga (2018). Supersonic spray combustion subject to scramjets: Progress and challenges. Progress in Aerospace Sciences, 21, 20-23. www.elsevier.com/locate/paerosci

25. Stony Brook (2020). Progress in Supersonic Spray Combustion Modeling. AIAA Life Member and Associate Fellow.

26. Stony Brook (2019). Evaluating the Correlations for Supersonic Spray Combustion. AIAA SciTech Forum, 7-11 January, San Diego, California.

27. Stony Brook (2018). Dynamics of Supersonic Spray Combustion. AIAA Propulsion and Energy Forum, July 9-11, Cincinnati, Ohio.

28. Tokyo Scinutsu Co. Ltd (2006). Application guide manual for surfcom series surface roughness \& waviness parameters. Tokyo, 96. 

